May 2000 • NREL/CP-520-28333

\title{
Model for Staebler-Wronski Degradation Deduced from Long-Term, Controlled Light-Soaking Experiments
}

B. von Roedern and J.A. del Cueto

Presented at the Materials Research Society's Spring Meeting

San Francisco, California

April 24-28, 2000
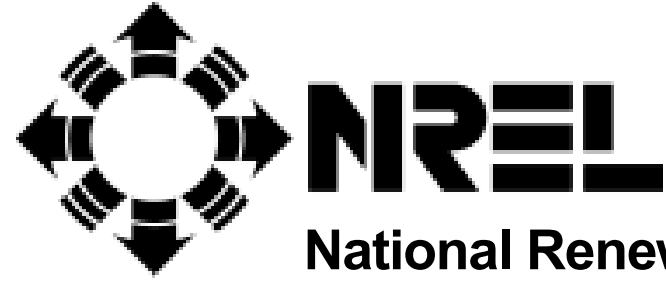

National Renewable Energy Laboratory

1617 Cole Boulevard

Golden, Colorado 80401-3393

NREL is a U.S. Department of Energy Laboratory

Operated by Midwest Research Institute $\bullet$ Battelle $\bullet$ Bechtel

Contract No. DE-AC36-99-G010337 


\section{NOTICE}

The submitted manuscript has been offered by an employee of the Midwest Research Institute (MRI), a contractor of the US Government under Contract No. DE-AC36-99G010337. Accordingly, the US Government and MRI retain a nonexclusive royalty-free license to publish or reproduce the published form of this contribution, or allow others to do so, for US Government purposes.

This report was prepared as an account of work sponsored by an agency of the United States government. Neither the United States government nor any agency thereof, nor any of their employees, makes any warranty, express or implied, or assumes any legal liability or responsibility for the accuracy, completeness, or usefulness of any information, apparatus, product, or process disclosed, or represents that its use would not infringe privately owned rights. Reference herein to any specific commercial product, process, or service by trade name, trademark, manufacturer, or otherwise does not necessarily constitute or imply its endorsement, recommendation, or favoring by the United States government or any agency thereof. The views and opinions of authors expressed herein do not necessarily state or reflect those of the United States government or any agency thereof.

Available electronically at http://www.doe.gov/bridge

Available for a processing fee to U.S. Department of Energy and its contractors, in paper, from:

U.S. Department of Energy

Office of Scientific and Technical Information

P.O. Box 62

Oak Ridge, TN 37831-0062

phone: 865.576 .8401

fax: 865.576.5728

email: reports@adonis.osti.gov

Available for sale to the public, in paper, from:

U.S. Department of Commerce

National Technical Information Service

5285 Port Royal Road

Springfield, VA 22161

phone: 800.553 .6847

fax: 703.605.6900

email: orders@ntis.fedworld.gov

online ordering: http://www.ntis.gov/ordering.htm

Printed on paper containing at least $50 \%$ wastepaper, including $20 \%$ postconsumer waste 


\title{
Model for Staebler-Wronski Degradation Deduced from Long-Term, Controlled Light-Soaking Experiments
}

\author{
Bolko von Roedern and Joseph A. del Cueto \\ National Renewable Energy Laboratory (NREL) \\ 1617 Cole Blvd., Golden, CO 80401-3393, U.S.A.
}

\begin{abstract}
Long-term light-soaking experiments of amorphous silicon photovoltaic modules have now established that stabilization of the degradation occurs at levels that depend significantly on the operating conditions, as well as on the operating history of the modules. We suggest that stabilization occurs because of the introduction of degradation mechanisms with different time constants and annealing activation energies, depending on the exposure conditions.

Stabilization will occur once a sufficient accumulation of different degradation mechanisms occurs. We find that operating module temperature during light-soaking is the most important parameter for determining stabilized performance. Next in importance is the exposure history of the device. The precise value of the light intensity seems least important in determining the stabilized efficiency, as long as its level is a significant fraction of 1-sun.
\end{abstract}

\section{INTRODUCTION}

Since about 1991, amorphous silicon (a-Si) research program guided by the National Renewable Energy Laboratory (NREL) has specified that all a-Si solar cell or photovoltaic (PV) module performances should be reported after stabilization. At that time, it was recommended to light-soak for 1000 hours with a device temperature of $50^{\circ} \mathrm{C}$ to establish stabilized performance. NREL carried out four light-soak tests using controlled exposure conditions to assess the details of degradation upon light-soaking [1,2]. Since about 1994, it became clear that outdoor exposure in Colorado typically resulted in higher degradation typically twice as much - than exposure at $50^{\circ} \mathrm{C}$ continuous light-exposure [2,3]. In previous publications, we surmised that this behavior was a fundamental a-Si property; because the same degradation trends were observed in modules from different manufacturers and with different initial efficiencies [4]. It was argued that this behavior could not be explained by a single degradation mechanism in which thermal or light-induced annealing would balance the lightinduced degradation. Instead, at least two mechanisms have to be involved: a fast one that can be annealed at typical module operating temperatures, and a slow one that does not recover measurably when annealing temperatures are limited to values below $70^{\circ} \mathrm{C}[4]$.

In a previous publication, we demonstrated that temperature and the temperature history during light-exposure clearly affected stabilized module efficiency [5]. In this work, we have extended the exposure temperatures further to lower values, resulting in further module degradation. Also, we have chosen to include a controlled light-soak cycle at $1 / 2$-sun (about 500 instead of $1000 \mathrm{~W} / \mathrm{m}^{2}$ ) to investigate our previous speculation that both exposure temperature and light-intensity affect the rates at which the fast and the slow mechanism can be introduced during light-stressing. These additional data points will assist in estimating the rates and ratios for the introduction and annealing behavior of the slow and fast mechanisms. 


\section{EXPERIMENT}

For this experiment, we continued light-soaking (ls) of most of the modules that were previously light-soaked for almost 5000 hours at various conditions [5]. We chose additional ls-cycles of 1227 hours at $1 / 2$-sun and $5^{\circ} \mathrm{C}$ module temperature ("cold soak"), and 343 hours at 1 -sun and $25^{\circ} \mathrm{C}$ or "cool soak." (This condition had been used twice before in the previous experiments and was hitherto called cold-soak because until then it was the lowest light-soak temperature.) This was followed by a 470 -hour hot-soak cycle at $50^{\circ} \mathrm{C}$ and 1 -sun intensity (the original standard light-soak conditions), followed by an additional 1000 hours of cool soak. Module performance was measured using the NREL Spire solar simulator at standard measurement conditions (simulated $1000 \mathrm{~W} / \mathrm{m}^{2}$ irradiance, spectrum for air mass 1.5 global spectrum, $25^{\circ} \mathrm{C}$ module temperature during measurement). While there is a significant amount of uncertainty in the absolute accuracy ( $\pm 10 \%$ or less) of the Spire simulator efficiency

measurements, there is a good reproducibility that allows determination of the degradation with higher relative accuracy ( $\pm 2 \%$ or less). Using the simulator, no consideration has to be given to spectral changes that are unavoidable in outdoor efficiency measurements. The total amount of degradation is somewhat dependent on the measurement system [1], but we believe that the amounts of degradation $\left(\eta / \eta_{\mathrm{o}}-1\right)$ reported here are typical for 1990-vintage a-Si PV modules within $+10 \%$ to $-20 \%$. In our experience, typically Spire simulator measurements result in slightly larger values of the initial efficiency and therefore slightly larger degradation percentages than outdoor measurements [1].

\section{RESULTS}

In Figures 1 (a), (b), and (c), we show the absolute efficiency values and the amount of degradation observed for the efficiencies and fill factors. We see that qualitatively, all modules, regardless of their efficiency level, show rather similar relative changes during these cycles. In Table 1, we show the stabilized performance levels of a triple-junction module with typical behavior for all light-soaking cycles carried out to date. Note that the duration of exposure cycles was chosen to result in stabilized performance for each cycle listed in this table. Figure 1 depicts the cycles for all modules, corresponding to rows 8 to 12 of Table 1 for module \#23. The timescale begins with 0 hours, and the relative efficiency and fill factor degradation $(\Delta \mathrm{FF})$ are with respect to the values obtained at the end the cycle corresponding to row number 7 . This was also the end point of the previously reported tests [5]. The caption in Figure 1 indicates the type of module, double- $(2 \mathrm{~J})$ or triple $(3 \mathrm{~J})$, and same (s-BG) or multibandgap (m-BG) device structures. The module descriptions were reported previously [5]. The unusual spike (increase of values or decrease in degradation) during the cycle corresponding to row 11 (at 2200 hours in Fig. 1) is due to accidental heating of the modules to temperatures up to $80^{\circ} \mathrm{C}$ for a period of 40 hours or less while the light source was turned off. 


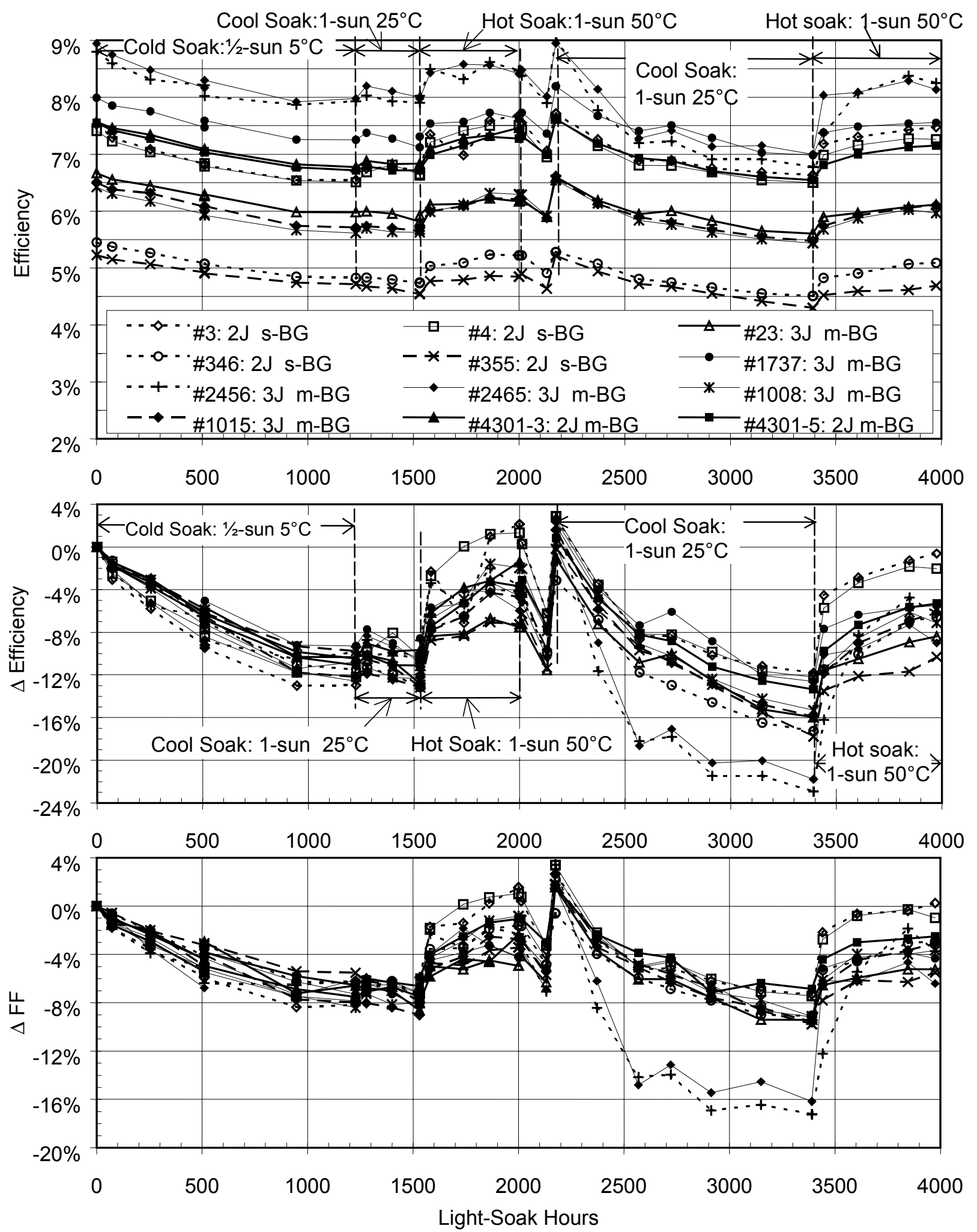

Figure 1: Module changes upon light-soaking: (a) absolute efficiency changes, (b) relative efficiency changes, and (c) relative fill factor changes. 
Table 1: Stabilized Values for Module 23 Since Initial Testing.

\begin{tabular}{|l|l|l|l|l|l|l|}
\hline $\begin{array}{l}\text { Row } \\
\#\end{array}$ & Condition & $\begin{array}{l}\text { Exposure hours } \\
\text { interval Total }\end{array}$ & $\begin{array}{l}\text { Stabilized } \\
\text { Efficiency }(\%)\end{array}$ & Fill factor $(\%)$ & $\begin{array}{l}\text { Degradation } \\
\left(\eta / \eta_{\mathrm{o}}-1\right)(\%)\end{array}$ \\
\hline 1 & initial & 0 & & $9.14($ initial) & 62.6 (initial) & 0 \\
\hline 2 & $1 \operatorname{sun} 50^{\circ} \mathrm{C}$ & 1000 & $(1000)$ & 7.30 & 53.6 & -20.1 \\
\hline 3 & $1 \operatorname{sun} 35^{\circ} \mathrm{C}$ & 840 & $(1840)$ & 6.61 & 52.7 & -27.7 \\
\hline 4 & $1 \operatorname{sun} 18^{\circ} \mathrm{C}$ & 987 & $(2877)$ & 5.91 & 48.3 & -35.3 \\
\hline 5 & $1 \operatorname{sun} 48^{\circ} \mathrm{C}$ & 368 & $(3245)$ & 6.63 & 52.4 & -27.5 \\
\hline 6 & $1 \operatorname{sun} 21^{\circ} \mathrm{C}$ & 977 & $(4222)$ & 5.91 & 48.7 & -35.3 \\
\hline 7 & $1 \operatorname{sun} 44^{\circ} \mathrm{C}$ & 595 & $(4817)$ & 6.51 & 51.4 & -28.8 \\
\hline 8 & $1 / 2 \operatorname{sun} 5^{\circ} \mathrm{C}$ & 1227 & $(6044)$ & 5.98 & 49.2 & -34.6 \\
\hline 9 & $1 \operatorname{sun} 25^{\circ} \mathrm{C}$ & 343 & $(6347)$ & 5.81 & 48.1 & -36.4 \\
\hline 10 & $1 \operatorname{sun} 50^{\circ} \mathrm{C}$ & 470 & $(6817)$ & 6.17 & 50.0 & -32.5 \\
\hline 11 & $1 \operatorname{sun} 25^{\circ} \mathrm{C}$ & 1392 & $(8209)$ & 5.61 & 47.7 & -38.6 \\
\hline 12 & $1 \operatorname{sun} 50^{\circ} \mathrm{C}$ & 583 & $(8792)$ & 6.11 & 49.9 & -33.2 \\
\hline
\end{tabular}

\section{DISCUSSION}

The difficulty of reconciling the experimental results arises from the fact that these results reported here simply could not be explained in terms of a single degradation mechanism being balanced by a competing thermal or light-induced annealing process. Whereas earlier results on PV modules [5,6], cells $[7,8]$, as well as on intrinsic films $[9,10]$ have clearly identified at least two kinds of metastable mechanisms produced by light exposure, such observations have been largely ignored in favor of Staebler-Wronski models that assume creation and annealing of neutral dangling bonds as the dominant mechanism controlling the electronic properties. All data suggest that multiple, potentially coupled mechanisms that occur on different timescales (e.g., "fast and "slow") are involved. However, our observations make previous assignment of the origin of the fast and slow mechanisms unlikely. For example, it has been argued that in solar cells, differences in the timescales might result from absorber and interface layer degradation, or different annealing mechanisms (light-induced versus thermal) have been invoked [8]. "Hysteresis" effects are important and have been observed both on film properties $[10,11]$ as well as in solar cells and PV modules. Hysteresis means that measuring an observable (y) (such as device efficiency or the mobility lifetime product in a film as a function of a variable, for example the sample or device temperature (T) used for light-soaking) will result in different values for $\mathrm{y}(\mathrm{T})$ depending on whether the temperature is ramped up or down or on the previous exposure history. Different observables $y(T)$ will degrade by different amounts and at different rates [12]. We believe that this behavior makes it impractical to predict precisely the stabilized state that an a-Si solar cell or PV module will attain for given operating conditions. However, because of the experimental data generated to date, somewhat quantitative empirical predictions are now possible.

Looking at the data in Table 1, we note that the module was exposed in five cycles, corresponding to rows $2,5,7,10$, and 12 , at essentially the same (standard hot-soak $50^{\circ} \mathrm{C}, 1$ - 
sun intensity) conditions, while the degradation increased progressively from $20.1 \%$ to $27.5 \%$, $28.8 \%, 32.5 \%$, and $33.2 \%$. Three cycles listed in rows 6,9 , and 11 (cool soaks at $25^{\circ} \mathrm{C}$, 1 -sun intensity) increased the degradation for this condition from $35.3 \%$ to $36.4 \%$ and $38.6 \%$. Clearly the stabilized performance level is not defined by the operating conditions and is affected by the previous exposure cycles. Figure 1 shows that after sufficient time in each cycle, the efficiency data saturate to particular values, and that subsequent degradation to even lower values in progressive cycles is not due to lack of exposure times in the previous cycles. Regardless of the amount of unrecoverable degradation, operation at $50^{\circ} \mathrm{C} 1$-sun recovers a sizeable fraction of the additional degradation induced by lower temperature exposure cycles. It is of interest to note that this recovery is likely to be temperature-activated. At $25^{\circ} \mathrm{C}$ there is very little recovery (row 9 in Table 1 and the cycle shown between 1227 and 1570 hours in Figure 1). In other words, the degradation introduced during the $1 / 2$-sun $5^{\circ} \mathrm{C}$ cold-soak cycle was essentially irreversible by simply returning to the prior (cool-soak, $25^{\circ} \mathrm{C}$ ) exposure conditions. On the other hand, this cold-soak cycle caused the stabilized efficiency after the subsequent cool soak cycle to decline by an additional $0 \%$ and 3\%. Figure 1 shows that the amount of degradation and the time constant are not very sensitive functions of light intensity, if this varies between 1 -sun and $1 / 2$-sun.

We found it impossible to parameterize the amounts of degradation and their recovery rates in terms of the temperature and intensity values used during the degradation cycles. The observations are consistent with our previous suggestion that stabilization occurs because of multiple self-limiting degradation mechanisms, rather than a balance between degradation and recovery. For a given exposure condition, this self-limitation is reached through varying combinations of recoverable ("fast") and nonrecoverable ("slow") mechanisms. Whenever recovery occurs, it is possible that in a subsequent exposure cycle more nonrecoverable degradation will be introduced, leading to the gradual decline of the stabilized performance as show in Table 1 and Figure 1.

For practical applications, we would like to emphasize that the degradation of amorphous silicon modules will stabilize. After almost 9000 hours of cycling modules in controlled experiments, the modules degraded somewhat more than that observed under outdoor exposure in the Golden (Colorado) climate. For example, companion modules to number 23 that were exposed outdoors at NREL degraded between 28\% and 31\% after 5 years of outdoor exposure, as compared to $33 \%$ after 12 indoor cycles. It is also worthwhile to point out that we provide a different explanation for performance differences of similar a-Si modules deployed in tropical versus high-latitude climates. Traditional theories attribute the performance advantage in the tropical climate to higher operating temperatures (i.e., greater annealing). Our series of light-soak tests suggest, however, that a significant portion of the performance advantage of the tropical exposure conditions arises from the fact that under tropical conditions modules are never exposed to light while they are "cool" or "cold." Conversely, a module that was first light-soaked at low temperatures would never fully recover the additional degradation when moved to a tropical climate. Finally, recent further optimization of a-Si PV modules has reduced the amount of light-induced degradation to levels below those shown in Table 1. This has largely been accomplished by modifying the a-Si material (using deposition schemes with higher hydrogen dilution and by optimizing the thicknesses of the component cells in the multi-junction devices). This has reduced degradation under outdoor conditions to about $20 \%$ in the best cases. However, even in these 
modules, the outdoor degradation remains measurably larger than that observed in indoor exposure tests carried out at $50^{\circ} \mathrm{C}$.

\section{ACKNOWLEDGEMENTS}

This work was supported by the U.S. Department of Energy under contract No. DEAC36-99-GO10337. The authors thank Jim Pruett for running the environmental test chambers to maintain the controlled exposure conditions and Steve Rummel and Allan Anderberg of NREL's Device and Module Characterization Team for carrying of the module efficiency measurements. One of the authors (BVR) gratefully acknowledges discussions with R. Crandall and C. Wronski.

\section{REFERENCES}

1. W. Luft, B. von Roedern, B. Stafford, and L. Mrig, Conference Record of the $23^{\text {rd }}$ IEEE Photovoltaic Specialists Conf. (1993), pp. 860-866.

2. W. Luft and B. von Roedern, Conference Record of the $24^{\text {th }}$ IEEE Photovoltaic Specialists Conf. (also $1^{\text {st }}$ World Conf. On Photovoltaic Energy Conversion), (1994), pp. 457-463.

3. L. Mrig, J. Burdick, W. Luft, and B. Kroposki, ibid, pp. 528-530.

4. B. von Roedern, B. Kroposki, T. Strand, and L. Mrig, Proccedings of the $13^{\text {th }}$ European Photovoltaic Solar Energy Conference (H.S. Stephens \& Associates, publishers), (1995), pp. 1672-1676.

5. J. del Cueto and B. von Roedern, Progress in Photovoltaics: Research and Applications 7, 101, (1999)

6. A.E. Delahoy, T. Tonen, J.A. Cambridge, M. Johnson, L. Michalski, and F.A. Kampas, Proceedings of the $8^{\text {th }}$ European Photovoltaic Solar Energy Conference (I. Solomon, B. Equer, P. Helm, Eds., Kluwer, Dordrecht), (1988) p. 646.

7. B. von Roedern, Materials Research Society Symposia Proc. "Amorphous Silicon Technology - 1991," Vol. 219, (1991), p. 493.

8. D. Redfield and R. Bube, Materials Research Society Symposia Proc. "Amorphous Silicon Technology - 1993," Vol. 297, (1993) p. 607.

9. D. Han and H. Fritzsche, American Institute of Physics Conference Proceedings "Optical Effects in Amorphous Semiconductors," Vol. 120, (1984), p. 296.

10. L. Mariucci, G. Sinno, C. Minarini, and A. Mittiga, Journal of Non-Crystalline Solids 198200, (1996), p. 482.

11. P. Stradins, M.Q. Tran, and H. Fritzsche, Journal of Non-Crystalline Solids 164-166, (1993), p. 175.

12. B. von Roedern, Applied Physics Letters 62, (1993), p. 1368. 


\section{REPORT DOCUMENTATION PAGE}

Form Approved OMB NO. 0704-0188

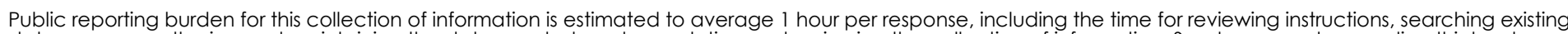

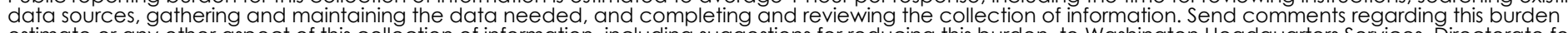

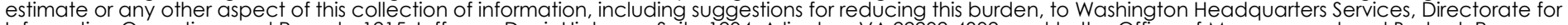

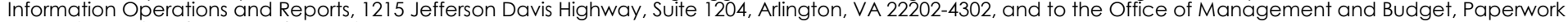
Reduction Project (0704-0188), Washington, DC 20503.

\begin{tabular}{|l|l|l|l|}
\hline 1. AGENCY USE ONLY (Leave blank) & $\begin{array}{l}\text { 2. REPORT DATE } \\
\text { May } 2000\end{array}$ & $\begin{array}{l}\text { 3. REPORT TYPE AND DATES COVERED } \\
\text { conference paper }\end{array}$ \\
\hline
\end{tabular}

4. TITLE AND SUBTITLE

Model for Staebler-Wronski Degradation from Long-Term, Controlled Light-Soaking Experiments

6. $A U T H O R(S)$

Bolko von Roedern and Joseph A. del Cueto

5. FUNDING NUMBERS

$\mathrm{C}$

TA: PV005001

7. PERFORMING ORGANIZATION NAME(S) AND ADDRESS(ES)

8. PERFORMING ORGANIZATION REPORT NUMBER

9. SPONSORING/MONITORING AGENCY NAME(S) AND ADDRESS(ES)

National Renewable Energy Laboratory

1617 Cole Blvd.

Golden, CO 80401-3393

10. SPONSORING/MONITORING AGENCY REPORT NUMBER

1. SUPPLEMENTARY NOTES

12a. DISTRIBUTION/AVAILABILITY STATEMENT

National Technical Information Service

12b. DISTRIBUTION CODE

U.S. Department of Commerce

5285 Port Royal Road

Springfield, VA 22161

13. ABSTRACT (Maximum 200 words)

Long-term light-soaking experiments of amorphous silicon photovoltaic modules have now established that stabilization of the degradation occurs at levels that depend significantly on the operating conditions, as well as on the operating history of the modules. We suggest that stabilization occurs because of the introduction of degradation mechanisms with different time constants and annealing activation energies, depending on the exposure conditions. Stabilization will occur once a sufficient accumulation of different degradation mechanisms occurs. We find that operating module temperature during light-soaking is the most important parameter for determining stabilized performance. Next in importance is the exposure history of the device. The precise value of the light intensity seems least important in determining the stabilized efficiency, as long as its level is a significant fraction of 1-sun.

14. SUBJECT TERMS

photovoltaics ; : Staebler-Wronski degradation ; light-soaking experiments

15. NUMBER OF PAGES

16. PRICE CODE

17. SECURITY CLASSIFICATION

18. SECURITY

CLASSIFICATION

OF REPORT

Unclassified

OF THIS PAGE

Unclassified

19. SECURITY CLASSIFICATION OF ABSTRACT

Unclassified
20. LIMITATION OF ABSTRACT

UL 